\title{
分散硬化 Al-Si 合金の不均一降伏挙動と降伏強さ
}

\author{
岸輝雄*・榊原 安英** \\ Yield stress and discontinuous yield behaviors in \\ dispersion hardened Al-Si alloys \\ UDC: $669.715^{\prime} 782: 539.382$ \\ Teruo KISHI* and Yasuhide SAKAKIBARA**
}

\begin{abstract}
A study on yield strength, especially on discontinuous yielding of dispersion hardened Al-Si single and polycrystals was carried out by tensile testing with the aid of acoustic emission signal analysis. $0.2 \%$ proof stress of the alloys is inversely proportional to the mean. dispersed particle spacing, indicating that Orowan's dislocation bowing-out mechanism controls the yield strength. High acoustic emission activity, AE peak in yielding, is observed in the initial deformation region in dispersed alloys. Discontinuous yielding occurs in the region of high activity AE peaks. Emitted energy within an AE peak is inversely proportional to the square of mean particle spacing and corresponds to stored energy of bowing-dislocation between two isolated particles. Quantitative distribution of particle spacing in a specimen is evaluated by analyzing the $\mathrm{AE}$ peak in yielding using the relation above obtained between Orowan stress, particle size and acoustic emission activity.
\end{abstract}

(Received February 22, 1984)

\section{1. 目的}

工学的に重要な分散硬化合金の強度, 特に降伏応力の 大きさは分散粒子の強さ, 粒子の形と分布および粒子の 体積率と粒子間隔等に支配されるが，その中で大きな効 果をもつのが粒子間隔の大きさである ${ }^{12.2) 。 O r o w a n ~ の ~}$ 降伏理論に従らと平均粒子間隔の逆数に比例して降伏応 力は上昇することになるが，この粒子間隔は一つの試験 片の中においても分布を示すのが普通であり, 当然, 試 験片内において降伏応力は変動していることになる。そ の結果として軟鋼のようなリューダース変形が生じてい ない材料においても不均一な降伏が材料内に進行するこ とになり，降伏挙動を理解するには，いつ，いかなる量 の変形が試験片内に生じているかを知ることが重要とな る。この不均一な降伏挙動を実験的に検出するには迄り 線観察に頼る手法が考えられるが，その解析は定量的に 変形量に関する情報を得るのが難しく, かつ動的に不均 一降伏を把握することは困難である。
形，割れに伴い生ずる弾性波を解析することにより，変 形，割れの大きさ，およびその持続時間に関する情報を 与え得る手法である ${ }^{3)}$ 。近年，その発生機構に関する取 り扱いに大きな進歩が見られ，変形に伴い生ずる $\mathrm{AE}$ 信 号の大小は局所的な転位の集団運動, より詳しくまとめ ると，転位の加速・減速に伴い生ずるひずみの大きさ， およびその持続時間の大小により支配されることが明ら かになつてきている4゙。このことは， $\mathrm{AE}$ が応力から見 ると局所的な応力集中の存在を，ひずみから見ると局所 的な不均一変形の大きさを変形中に動的に把握しらる可 能性を示している5)。

そこで本研究は, 単結晶・多結晶の $\mathrm{Al}-\mathrm{Si}$ 分散型合金 を用い，降伏に伴い発生する AE 信号を計測・解析する ことにより，分散粒子の不均一分布による降伏挙動を理 解することを目的としている。さらに，その発展として 分散粒子の分布および平均降伏応力を $\mathrm{AE}$ 計測より求め る手法を提案しようとするものである。

一方, Acoustic Emission（以下 AE と略す）技法は変

* 東京大学工学部境界領域研究施設 (東京都)。Institute of Interdisciplinary Research, Faculty of Engineering, The University of Tokyo (Tokyo).

** 動力炉，核燃料開発事業団。Power Reactor \& Nuclear Fuel Development Corp. 


\section{2. 実験方法}

\section{1 試験材料}

用いた材料は $99.99 \%$ の純アルミニウムおよび $\mathrm{Si}$ 含有 量 $0.6 \mathrm{wt} \%, 1.3 \mathrm{wt} \%, 1.5 \mathrm{wt} \%$ の Al-Si 合金であり，そ の化学組成は Table 1 に示されている。

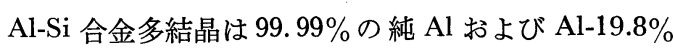
$\mathrm{Si}$ 母合金を用い，目標の組成を得るよ5に調整しつつ， 溶解・鋳造を行い, その後 $3 \mathrm{~mm}$ 板厚まで圧延を行つ た。フライス加工により Fig. 1 の形状の試験片を作製 し, $580^{\circ} \mathrm{C} \times 1 \mathrm{hr}$ の溶体化処理を行い水水中に焼入れし て $2 \mathrm{hr}$ 保持した。シリコン粒子の大きさ, 粒子間隔を 調整するため, その後 $250 \sim 300^{\circ} \mathrm{C}$ 温度領域で数時間の 時効処理を行つている。この材料の平均結晶粒 径は約 $500 \mu \mathrm{m}$ であつた。

$\mathrm{Al}-\mathrm{Si}$ 合金単結晶は Al-1.3wt\% $\mathrm{Si}$ 合金試験片からン フトモールドを用いたブリッジマン法により作製した。

Table 1 Chemical composition of Al-Si alloys.

\begin{tabular}{rrrrrrr}
\hline & $\mathrm{Si}$ & $\mathrm{Fe}$ & $\mathrm{Cu}$ & $\mathrm{Mn}$ & $\mathrm{Mg}$ & $\mathrm{Zn}$ \\
\hline $\mathrm{A}$ & 0.6 & .01 & .00 & .00 & .00 & .00 \\
\hline $\mathrm{B}$ & 1.3 & .02 & .00 & .00 & .00 & .00 \\
\hline $\mathrm{C}$ & 1.5 & .02 & .00 & .00 & .00 & .00 \\
\hline
\end{tabular}

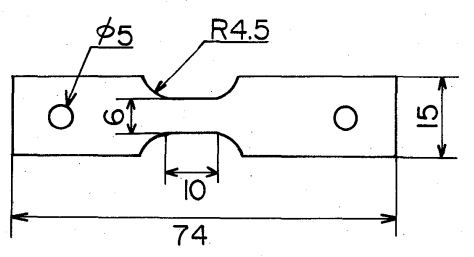

Fig. 1 Shape and size of specimen for tensile test.

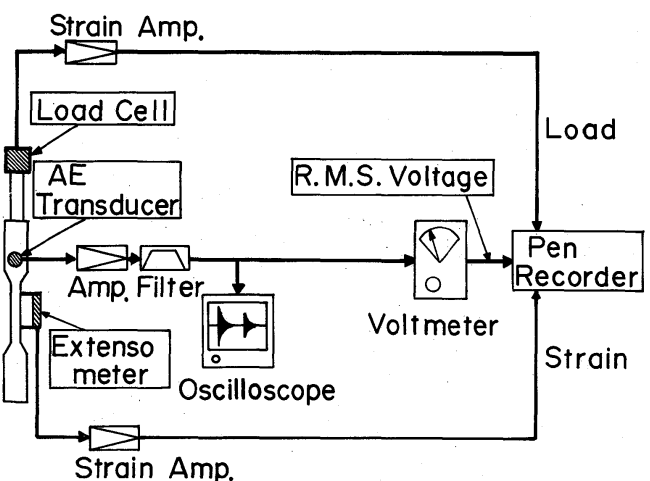

Fig. 2 Block diagram for tensile test including instrumentation set-up for acoustic emission measurement. $580^{\circ} \mathrm{C} \times 1 \mathrm{hr}$ 真空中で均質化処理を施し，再び $580^{\circ} \mathrm{C} \times$ $1 \mathrm{hr}$ の溶体化処理後水水中に焼入れを行い, $250 \sim 300^{\circ} \mathrm{C}$ 温度範囲で時効処理を行い粒子間隔を調整した。作製し た単結晶の結晶方位は Schmid 因子が0. 44〜0.48の間に 分布している。

一方, 純 $\mathrm{Al}$ 多結晶試験片は同一形状の圧延材より, また単結晶は Al-Si 合金と同様ブリッジマン法により作 製し，その方位も同一の範囲のものを用いている。

\section{$2.2 \mathrm{AE}$ 計測}

Fig. 2 にE 計測系のブロック図が示されている。図 に示したよらに試験片上端, 側面部に $140 \mathrm{KHz}$ に共振 周波数を持つ圧電型変換子を取りつけている。変換子に よる検出信号は $70 \mathrm{~dB}$ の増幅後, $20 \sim 200 \mathrm{KHz}$ のフィ ルターを通過し，オシロスコープにより波形および実効 值電圧計により実効数電圧 (R.M.S. 電圧) を計測 し, ペンレコーダーに応力ーひずみ曲線と同時に記録されて いる。また, 試験に先立ち, あらかじめ充分な予荷重を 加え, Kaiser 効果を利用して試験片チャック部よりの 雑音を除いている。解析のしきい值電圧は; 変換子入力 換算で R.M.S. 電圧 $4 \mu \mathrm{V}$ とし, 電気雑音の影響を除い ている。

\section{3 試験方法}
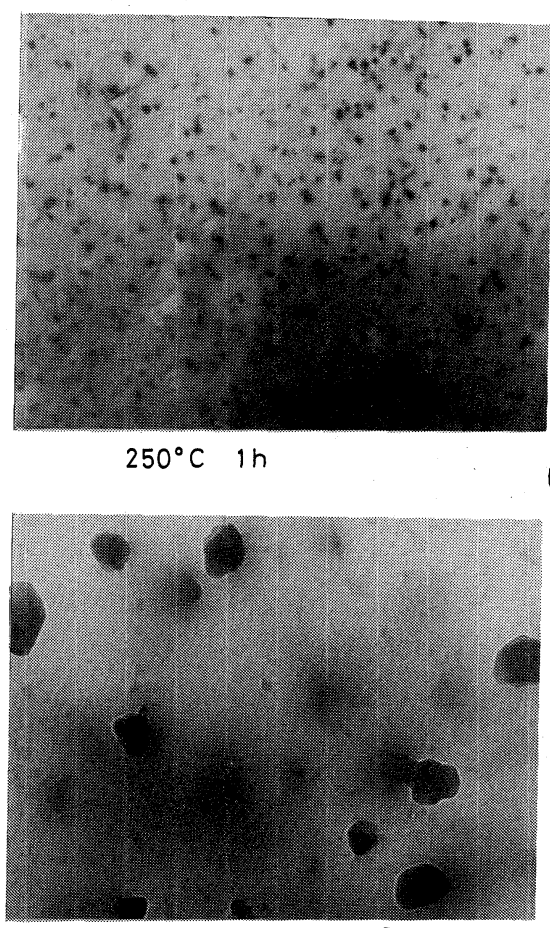

$0.4 \mu \mathrm{m}$

$300^{\circ} \mathrm{C} \quad 10 \mathrm{~h}$

Photo 1 Silicon precipitates in aged Al-1.3 wt\% $\mathrm{Si}$ alloy. (a) aged $1 \mathrm{~h}$ at $250^{\circ} \mathrm{C}$. (b) aged $10 \mathrm{~h}$ at $350^{\circ} \mathrm{C}$. 


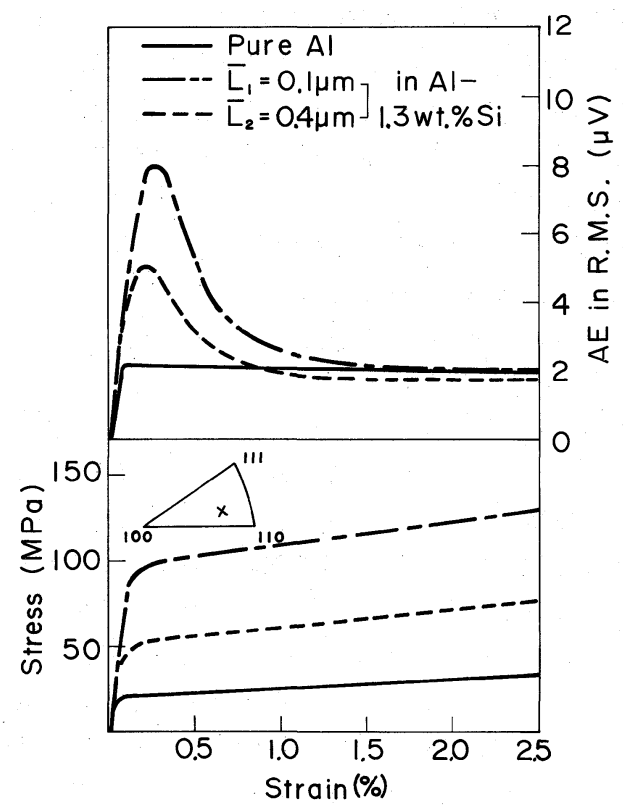

(a) Single Crystals

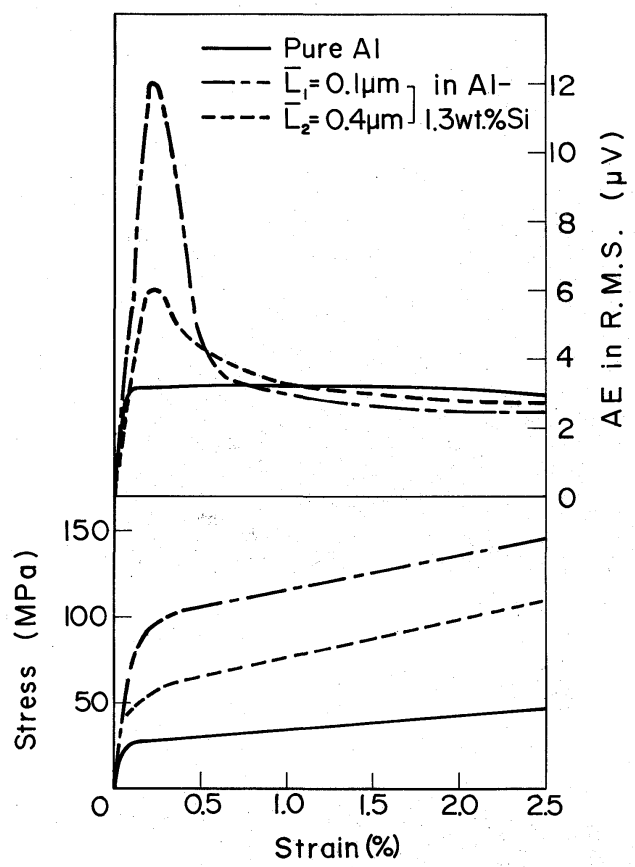

(b) Polycrystals

Fig. 3 Stress-strain relations and acoustic emission signals during tensile test in pure $\mathrm{Al}$ and dispersion-hardened Al-Si alloys.

本実験に使用した引張り試験はインストロン型試験機 (Autograph IS-10) であり, 試験は室温で行い, 引張り 速度は $0.5 \mathrm{~mm} / \mathrm{min}$ を用いた。これはひずみ速度 8 .

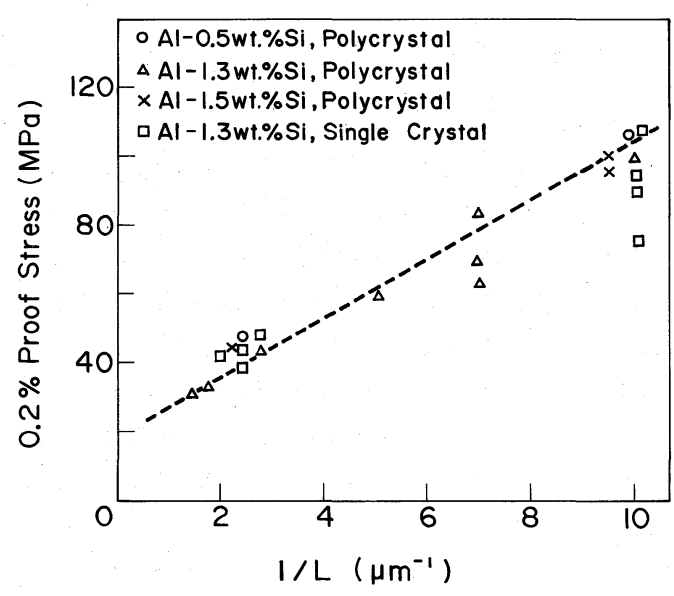

Fig. 4 The relationship between mean dispersed particle spacing $\mathrm{L}$ and $0.2 \%$ proof stress in poly and single crystals.

$10^{-4} / \mathrm{sec}$ に相当する。また, 試験はすべて室温, 大気中 で行つている。

\section{3. 実験結果}

\section{1 分散粒子間隔之 $0.2 \%$ 耐力}

Photo 1 亿 Al-1.3 wt\% Si 合金多結晶の $250^{\circ} \mathrm{C} \times 1 \mathrm{hr}$, および $350^{\circ} \mathrm{C} \times 10 \mathrm{hr}$ 時効処理材の 透過電子顕微鏡写真 の観察結果を示す。分散粒子の形状はほぼ円形（立体的 には球状) で, 平均の粒子径は 100 200 $\mathrm{A}, 600 \sim 800 \AA$ であり，かつ粒子間隔の平均值は $0.14 \mu \mathrm{m}$ および 0.45 $\mu \mathrm{m}$ である。このよらにして各材料の平均粒子間隔をす ベての材料について求めている。次に $\mathrm{Al}-1.3 \mathrm{wt} \% \mathrm{Si}$ お よび純 $\mathrm{Al}$ の引張り試験，および R.M.S. 電圧で示した $\mathrm{AE}$ 計測の結果が Fig. 3 に示されている。Fig. 3(a) は 単結晶, Fig. 3(b) は多結晶の結果であるが, 共に分散 Si の存在により，かつその平均粒子間隔の減少に伴い変 形抵抗は増大している。

そこで $\mathrm{Si}$ 含有量が $1.3,1.5 \mathrm{wt} \%$ と異なる 3 つの材料 について平均粒子間隔と $0.2 \%$ 耐力の関係を示したのが Fig. 4 である。この図から明らかなように単結晶, 多結 晶を問わず, $\mathrm{Si}$ 含有量の大小に関係なく $0.2 \%$ 耐力 $\sigma_{0.2}$ と平均粒子間隔の間には，この試験条件において下記の 関係がよく成立している。

$$
\sigma_{0.2}=24+\frac{80}{L}(\mathrm{MPa})
$$

定数項は存在するが，このように $0.2 \%$ 耐力が結晶粒界 等の存在に関係なく，粒子間隔の逆数に比例するという 実験結果は，この分散硬化合金の降伏が Orowan 型の 機構に支配されている可能性を示している1。

\section{2 降伏に伴う $\mathbf{A E}$ 挙動}


オシロスコープ上で観察された $\mathrm{AE}$ は連続型の信号で ある。Fig. 3(a) に示したように単結晶の塑性変形に伴 い発生する $\mathrm{AE}$ は, 純 $\mathrm{Al}$ ではひずみ量に拘らずほぼ1.8 $\mu \mathrm{V}$ 程度の值を示している。これ対して $\mathrm{Al}-\mathrm{Si}$ 合金で は変形初期，すなわち降伏に伴い高い $\mathrm{AE}$ 活動度を示し ほぼ0.5\%ひずみにいたると純 $\mathrm{Al}$ と同様な $\mathrm{AE}$ レベル になつている。また，分散粒子間隔の小さいものほど降 伏に伴ら AE レべる注大きい。以後, この降伏域に生ず る高い $\mathrm{AE}$ 信号の挙動を降伏に伴う $\mathrm{AE}$ ピークと呼ぶこ とにする。

次に Fig. 3(b) は多結晶の結果を示している。純 $\mathrm{Al}$ で は単結晶と同じくひずみ量に関係なく $2 \mu \mathrm{V}$ 程度の一定 值を取つている。これに対して $\mathrm{Al}-\mathrm{Si}$ 合金では単結晶と 同じく変形初期に降伏に伴う $\mathrm{AE}$ 信号のピークが見ら れ，平均粒子間隔の小さい材料の方が高い值を示してい る。

単結晶と多結晶の相違に関しては, 若干多結晶の R.M.S. 電圧の方が大きいが，その発生パターンには大 きな差異は認められず，この降伏の $\mathrm{AE}$ ピークには結晶 粒径は大きな影響を与えていないといえる。これに関し て著者らは, 変形に伴う $\mathrm{AE}$ の結晶粒度依存性について 研究を行つてきたが4)，このような粗粒では粒界は $\mathrm{AE}$ 信号に影響を与えないことを明らかにしている。また， 平均粒子間隔の異なる材料に抒いても固溶 $\mathrm{Si}$ 量の大き さはほとんど変化しないと考えられるので，この降伏の $\mathrm{AE}$ ピークは分散粒子によるものと考えられる。

それゅえ，ここに見い出された降伏に伴ら $\mathrm{AE}$ ピーク は分散粒子によるものであり，そのピークの高さは平均 粒子間隔が小さくなるにつれて大きくなると結 論でき る。

次に, 降伏の $\mathrm{AE}$ ピークの $\mathrm{AE}$ エネルギーと平均粒子 間隔の関係を求めたのが Fig. 5 である。Fig. 5(a) に示 したように変形が進んで定常的な大きさを示す $\mathrm{AE}$ レべ ルと降伏の $\mathrm{AE}$ ピークを二つの直線で近似し，このピー クを 10 等分に分割し, 各々の分割要素の平均 R.M.S. 電 圧 $R_{i}$ を用い

$$
E=\sum_{i=1}^{10}\left(R_{i}^{2}-R_{0}^{2}\right)
$$

の関係により $\mathrm{AE}$ ピークの $\mathrm{AE}$ エネルギー $E$ を求めて いる。ここに $R_{0}$ は計測系の雑音レベルであるが，Fig. 3 ではすでにこの $R_{0}$ を除いた有効電圧が示されているの で，(2)式の $R_{0}$ の項は無視して $\mathrm{AE}$ エネルギーを求めう る。また，この $\mathrm{AE}$ ピークの生じている範囲で降伏が生 じていると考えられるので，図に示したように降伏域 $\Delta \varepsilon_{y}$ が定義しうる。Fig. 5(b) にこらして求めたAEピーク の $\mathrm{AE}$ エネルギーE と平均粒子間隔の逆数の二乗 $(1 / \mathrm{L})^{2}$ の関係がプロットされている。単結晶, 多結晶の相違抒

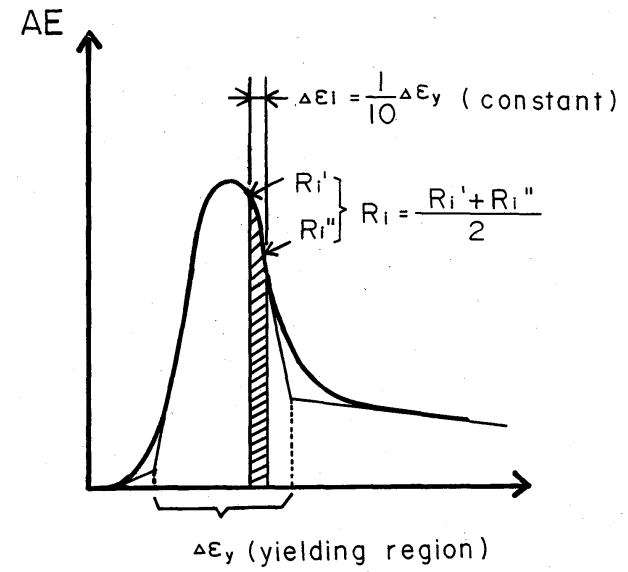

(a)

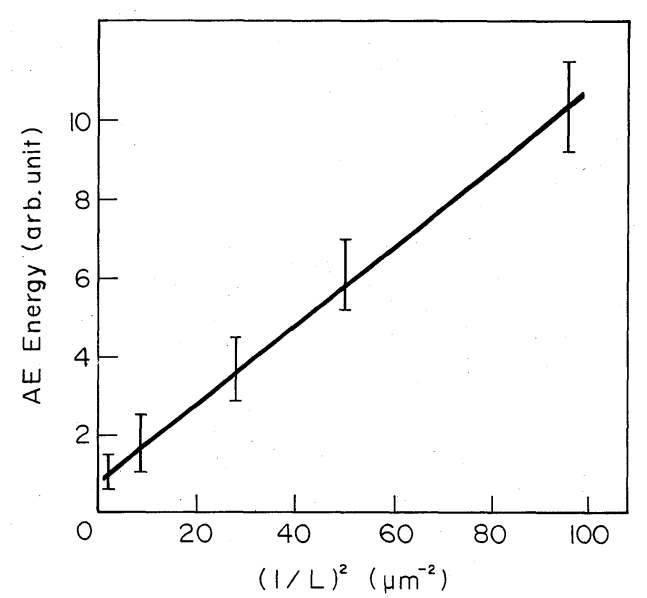

(b)

Fig. 5 Relationship between dispersed particle spacing and $\mathrm{AE}$ energy within $\mathrm{AE}$ peak in yielding.

(a) Schematic diagram to obtain $\mathrm{AE}$ energy within AE peak.

(b) Relation between particle spacing and $\mathrm{AE}$ energy.

よび含有 $\mathrm{Si}$ 量の大きさに依存せず，両者の間には

$$
E \propto\left(\frac{1}{L}\right)^{2}
$$

の関係がよく成立している。

\section{4. 考 察}

\section{1 降伏の AE ピーク}

降伏の AE ピークの発生機構について考察を進める。 ここでは平均粒子間隔の異なる材料の $\mathrm{AE}$ エネルギーの 変化, すなわち(3)式の関係について転位の張り出しに要 するエネルギーとの対比を試みる。Fig. 6 亿示すように 平均粒子間隔 $\bar{L}$ の分散粒子の間を転位が張り出し, 張 


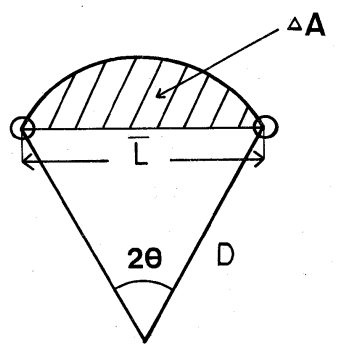

Fig. 6 Diagram of dislocation bowing between dispersed particles.

り出し角 $2 \theta$ のときの曲率半径を $D$ とする。このとき, 転位が張り出すことにより掃かれた斜線部の面積 $\Delta A$ は1),

$$
\begin{aligned}
\Delta A & =D^{2} \theta-D^{2} \cos \theta \cdot \sin \theta \\
& =\frac{2}{3} D^{2} \theta^{3} \\
& =\frac{L^{3}}{12 D}
\end{aligned}
$$

で与えられる。また, 張り出した転位が通り抜ける Orowan 応力 $\tau_{c}$ は,

$$
\tau_{c}=\alpha \cdot \frac{\mu b}{\bar{L}}
$$

で与えられるので，一本の転位が通り抜けるときになさ れる仕事 $d Q$ は， $d_{y}$ を転位線の素片， $d_{D}$ をそれに垂直 方向の距離とすると,

$$
\begin{aligned}
d Q & =\iint \frac{F}{2} \cdot d_{y} \cdot d_{D} \\
& \approx \frac{F}{2} \cdot \Delta A
\end{aligned}
$$

で近似的に表される。ここで $F$ は $F=\tau_{c} \cdot b$ であり，転 位に加わる臨界の力である。

(4) (6)式により $D=\bar{L} / 2 / \sin \theta$ の関係を用いると $d Q$ は

$$
d Q=\alpha^{\prime} \cdot \bar{L} \quad\left(\alpha^{\prime}=\frac{\alpha \mu b^{2}}{12} \cdot \sin \theta\right)
$$

となり, $\bar{L}$ に比例した值が得られる。このような機構を 生ずる場所の数 (サイトの数) は, 試験片内の変形域の 体積を $V$ とすると $V / L^{3}$ 個所あるので, 全仕事量は

$$
\begin{aligned}
Q & =d Q \cdot \frac{V}{L^{3}} \\
& =\alpha^{\prime} \cdot V \cdot \frac{1}{L^{2}}
\end{aligned}
$$

となる。それゆえに, 分散粒子間隔を通り抜ける転位が 受ける仕事量は, 平均分散粒子間隔の逆数の 2 乗に比例 する。

この結果は Fig. 5 の結果とよく対応し, 降伏に伴う $\mathrm{AE}$ ピークの $\mathrm{AE}$ エネルギー $E$ と(8)式の $Q$ は

$$
E \propto Q
$$

の関係にある。このことは，分散粒子の間を転位が張り 出すときに貯えられた仕事量が $\mathrm{AE}$ エネルギーに比例す ることを意味し，ここに見い出された降伏に伴う AE ピ ークは，転位が分散粒子を通りぬけるオロワン機構によ り生じたものと結論される。

オロワン応力に関しては，近年その取り扱いに進歩が 見られ，粒子半径および転位芯半径を考慮し ${ }^{5), 6)}$ かつ有 効な平均粒子間隔を粒子の分布より求める方法が提案さ れている 2 ,6),7)。しかしながら，これらの寄与は(5)式に 対して $10 \%$ 以下の小さなものであり，本考察では，(5)式 を用いて解析を進める。

\section{2 分散粒子の分布}

前節 4.1 では平均粒子間隔と $\mathrm{AE}$ エネルギーの関係よ り降伏に伴う AE ピークが，オロワン型機構に対応する ことを示してきたが，ここではこの考え方を発展させ， 一つの試験片内での不均一降伏の進行と分散粒子間隔の 分布について考察を進める。

Fig. 7 は AE ピーク，応力および分散粒子間隔の関係 を示したものである。今, Fig. 7(a) の斜線で示した AE ピーク内の $i$ 番目の分割個所での面積を $d S_{i}$ とする。こ こでの外から加えられている応力が Fig. 7(b) に示す $\sigma_{i}$ であり，また（1)式の関係を一つの試験片内の降伏応力

(a) $A E$

(b)Stress

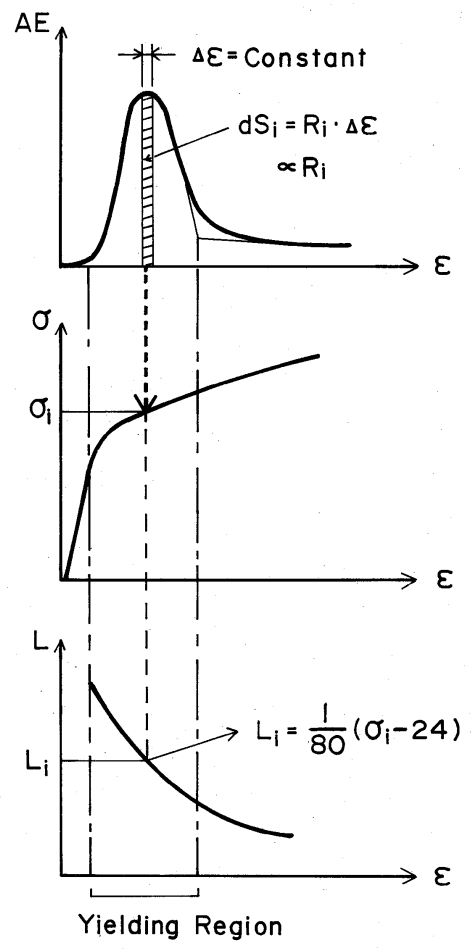

Fig. 7 Schematic diagram showing the relation between $\mathrm{AE}$, flow stress and particle spacing. 


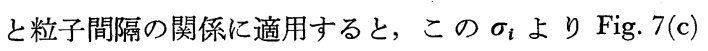
に示したように $d S_{i}$ で降伏している領域の分散粒子間隔 $L_{i}$ が得られることになる。

ここで, Fig. 5 に示すように $d S_{i}=\int R d \varepsilon$ の関係にあ り, 分割要素の幅 $\Delta \varepsilon=1 / 10 \Delta \varepsilon_{y}$ としているので, $d S_{i}$ は 近似的に $d S_{i}=R_{i} \cdot \Delta \varepsilon$ と表示でき, $\left(d S_{i}\right)^{2} \propto R_{i}{ }^{2}$ は $\mathrm{AE} 工$ ネルギーに比例した值を示す。

今， $L_{i}$ の粒子間隔を持つ場所（サイト）の数を $N_{i}$ と し，この $L_{i}$ を通過するときの仕事を $d Q_{i}$ とすると， (7) (8)式より,

$$
\begin{aligned}
\left(d S_{i}\right)^{2} & \propto d Q_{i} \times N_{i} \\
& \propto\left(\alpha \cdot L_{i}\right) \times\left(\frac{V_{i}}{L_{i}^{3}}\right)
\end{aligned}
$$

の関係が得られる。 $\mathrm{AE}$ ピーク内で $d S_{i}$ の面積を有する 領域の粒子間隔 $L_{i}$ は， $\sigma_{i}$ を用いて Fig. 7 の関係により 求めることができるので, $(10)$ 式より $d S_{i}$ の分布から一 つの試験片内の分散粒子の間隔の分布 $N_{i}$ を求めらるこ とになる。Al-1.3 wt\% $\mathrm{Si}$ 合金における，(10)式より求 めた分散粒子間隔の分布が Fig. 8 に示されている。図に

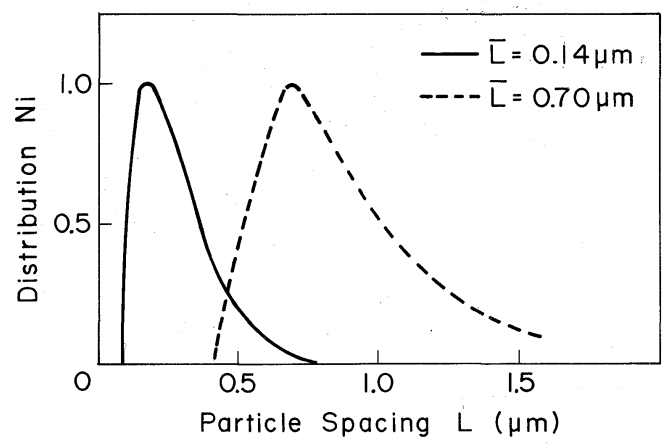

Fig. 8 Distribution of dispersed particle spacing in a specimen estimated by $\mathrm{AE}$ peak in yielding.

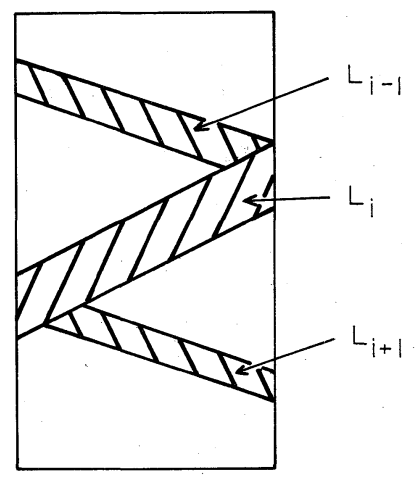

Fig. 9 Schematic diagram of inhomogeneous yielding depending on the dispersed particle spacing.
Table 2 Mean yield stress $\sigma_{y}$ evaluated by inhomogeneous yielding and $0.2 \%$ yield stress.

\begin{tabular}{ccc}
\hline & $\sigma_{y}(\mathrm{MPa})$ & $\begin{array}{l}0.2 \% \text { proof } \\
\text { stress }(\mathrm{MPa})\end{array}$ \\
\hline $0.5 \mathrm{wt} \% \mathrm{Si}$ & 74 & 71 \\
& 32 & 34 \\
\hline $1.3 \mathrm{wt} \% \mathrm{Si}$ & 113 & 110 \\
& 49 & 48 \\
\hline
\end{tabular}

示されたように電子顕微鏡観察で $0.14,0.7 \mu \mathrm{m}$ の平均間 隔をもつ材料も， $0.1 \sim 0.8 \mu \mathrm{m}, 0.4 \sim 1.6 \mu \mathrm{m}$ の粒子間隔 分布を有することになる。

このよらに AE 計測により分散粒子閭隔の分布を求め らるが,ここで求めた分布は,すべての粒子間隔を直接求 めたものではなく, Fig. 9 に模式的に示すよらに平均で $L_{i}$ の間隔を持つ粒子の集団領域（サイト）が同時に降伏 したものであり，それゆえ， $L_{i}$ の中にも微視的には再び 粒子間隔の分布が存在することになる。しかしながら， このよらなサイト単位で降伏が進行する限り，ここで求 めた粒子間隔の分布は降伏を直接支配するものであり， その意味で $(10)$ 式より求めた $N_{i}$ を「有効粒子間隔分布」 と呼ぶことができるであろう。

\section{3 平均降伏応力}

上述の考えに従らと，材料の降伏域 $\Delta \varepsilon_{\boldsymbol{Y}}$ (降伏に要す る塑性ひずみ), および降伏応力も実際に進行している 降伏に従つて定義する必要がある。Fig. 3 に見られるよ らにこれらの材料では，塑性ひずみ約 $0.5 \%$ で降伏が完 了し, 以後均一変形に近い形で変形が進行しているとい える。また，平均降伏応力 $\sigma_{y}$ を次式で定義してみると

Table 2 の結果が得られることになる。

$$
\bar{\sigma}_{y}=\sum_{i} \frac{\sigma_{i} \cdot N_{i}}{N}
$$

先に Fig. 3 で求めた $0.2 \%$ 耐力も併記しているが， $\bar{\sigma}_{\boldsymbol{y}}$ の 方が若干高い值を示している。*

以上，分散硬化合金においては，顕著な不均一変形の 様相が表れない場合にも試験片内に不均一な降伏が進行 し，それが AE 信号により定量的に評価しらることが判 明したといえる。

*しかしながら，このように変形量を考慮した降伏応 力 $\bar{\sigma}_{y}$ と従来便宜的に用いられてきた $0.2 \%$ 耐力はか なりよい一致を示し,かつ本研究で見いだされた $\mathrm{AE}$ 信号の最大值は $0.2 \%$ 耐力に近い応力が生じており, 少なくとも本材料では $0.2 \%$ 耐力は，新しい降伏が 最も頻度高く生じている応力に対応しているといえ よう。 


\section{5. 結 論}

分散硬化合金の降伏強度，特に降伏の不均一進展を理 解する目的で，球状分散粒子を形成する $\mathrm{Al}-\mathrm{Si}$ 合金 (0.6, $1.3,1.5 \mathrm{wt} \% \mathrm{Si})$ 単結晶, 多結晶を用いて引張り試験を 行い，同時にアコースティック・エミッション (AE) を 計測することにより以下の結論を得ている。

(1) 応力一ひずみ曲線から求められた $0.2 \%$ 耐力の大 きさは, 単結晶, 多結晶の相違および $\mathrm{Si}$ 含有量にかか わらず，平均分散粒子間隔の逆数に比例する。これは $0.2 \%$ 耐力が, Orowan 型の転位機構に支配されてい ることを示している。

(2) 分散粒子を含む材料では，変形初期に大きな $\mathrm{AE}$

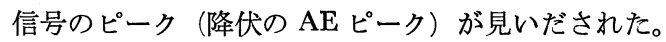
この $\mathrm{AE}$ ピークは約 $0.5 \%$ の塑性ひずみ幅で生じ, 結晶 粒界に依存せず，平均分散粒子の間隔が小さい程，大 ききな值を示した。

(3) 降伏の $\mathrm{AE}$ ピークの $\mathrm{AE}$ エネルギーは平均分散粒 子間隔の 2 乗に逆比例し，これは転位が分散粒子の間 を張り出すときのエネルギーに比例しており,この $\mathrm{AE}$ ピークは, オロワン機構で降伏が進行している過 程に対応しているものと結論された。

(4) 一つの試験片では, 降伏はこの $\mathrm{AE}$ ピークの内で 不均一に進展し，(1)，(3)で求めた $\mathrm{AE}$ エネルギー一応 カ一粒子間隔の関係より, 材料内の分散粒子間隔の分
布が定量的に得られている。また，分散粒子間隔の分 布より平均降伏応力の值が求められた。

この研究を進めるにあたり, 宇宙科学研究所, 堀内良 教授, 栗林一彦助教授に有益な助言, 討論をしていただ いたことに感謝します。

この研究は, 科学研究費 (試験(2)) の補助により行わ れたことを付記します。

\section{参 考 文 献}

1) P. Haasen: Phyaikalische Metallkunde, SpringerVertag, (1974), 邦訳 岸 輝雄他, 金属強度の 物理学, アグネ (1980), p. 274

2）松浦圭助：日本金属学会セミナーテキスト，複 合材料の現状，問題の展望，(1980)，p. 71

3) 岸 輝雄: 軽金属, 第31巻, 第 4 号, (1981), p. 266

4) K. Kuribayashi and T. Kishi: Advances in Acoustic Emission, edited by Dunegan, Am. Soc. for Nondestructive Testing, (1979), p. 112.

5）岸 輝雄, 楖原安英, 小幡義彦, 堀内 良 : 日 本金属学会誌，第41巻，第 9 号, (1977), p. 890

6) L. M. Brown and R. K. Ham: Strengthening Methods in Crystals, edited by A. Kelly and R. B. Nicholson, Elsevier, (1971), p. 7.

7) M. F. Ashby: Physics of Strength and Plasticity, edited by A. S. Argon, The M. I. T. Press, (1969), p. 113. 